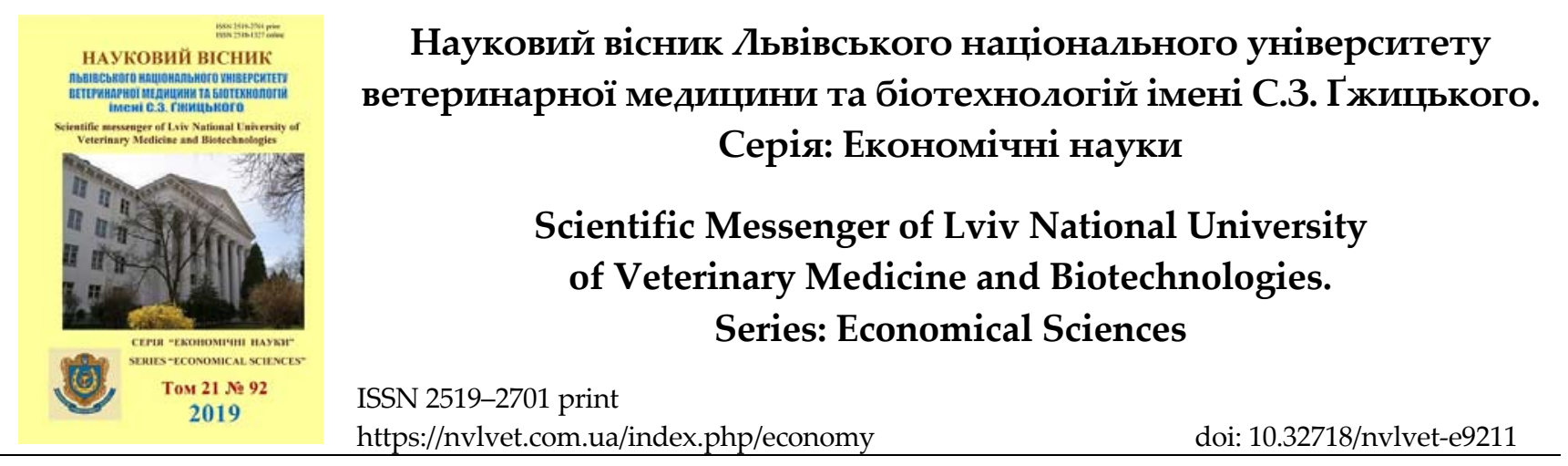

UDC 338.432:330.341.1

\title{
Influence of investment and innovation activity in the agrarian sector of agroindustrial complex on development of rural territories
}

\author{
O.V. Kopytko, R.V. Seniv, I.M. Laganjak \\ Stepan Gzhytskyi National University of Veterinary Medicine and Biotechnologies Lviv, Ukraine
}

Article info

Received 23.01.2019

Received in revised form 25.02.2019

Accepted 26.02.2019

Stepan Gzhytskyi National University of Veterinary Medicine and Biotechnologies Lviv,

Pekarska Str., 50, Lviv, 79010, Ukraine.

Tel.: +38-096-340-68-18

E-mail: o-kopytko@ukr.net senivrv@ukr.net

prostoivanka10@gmail.com
Kopytko, O.V., Seniv, R.V., \& Laganjak, I.M. (2019). Influence of investment and innovation activity in the agrarian sector of agroindustrial complex on development of rural territories. Scientific Messenger of Lviv National University of Veterinary Medicine and Biotechnologies. Series: Economical Sciences, 21(92), 68-74. doi: 10.32718/nvlvet-e9211

To date, the development of the economy is determined by the high dynamics of economic and technological transformations, which is intensified by competition in a number of industries, which leads to changes in the needs of society. These factors come to the fore due to the rapid development of information technologies and the globalization of the global economy, that in such conditions, enterprises of the agrarian sector of agrarian and industrial enterprises need to continuously improve innovation and technological development, in order not to lose competitiveness and position on the external and internal market of food. Innovations are expanding the capabilities of agricultural producers, influencing the socioeconomic development of rural areas. Therefore, it is relevant to increase the intensification of agricultural production on the basis of the active introduction of innovations in the agrarian sphere of Ukraine. Currently, successful farmers and owners of large agroholdings are seriously interested in modern technology of land cultivation and livestock farming, as well as high-tech. They are ready to invest heavily in their lands - and their interests are supported by domestic and foreign partners. The association of territorial communities (OTG) focuses on the need to consider and legislatively establish mechanisms for protecting the interests of peripheral rural communities, support for the cooperation of small agricultural producers, and promote diversification of the rural economy, which will increase employment and reduce the migration of the rural population. This involves stimulating entrepreneurial activity, diversifying the employment of the rural population (green tourism, crafts and crafts, services), mechanisms of influence of public self-government and regional self-regulation on the socio-economic components of communities and territories.

Key words: innovations, agrarian sector of agroindustrial complex, diversification, rural territories, territorial communities.

\section{Вплив інвестиційно-інноваційної діяльності в аграрній сфері АПК на розвиток сільських територій}

\author{
О.В. Копитко, Р.В. Сенів, І.М. Лаганяк
}

Львівський національний університет ветеринарної медицини та біотехнологій імені С.3. Гжицького, м. Львів, Україна

Нині розвиток економіки визначається високою динамікою економіко-технологічних перетворень, шзо підсилюється конкурениією в ряді галузей і призводить до змін потреб суспільства. Ці фактори виходять на периий план за рахунок стрімкого розвитку інформаційних технологій і глобалізачії світової економіки, щуо в таких умовах підприємствам аграрного сектору АПК необхідно постійно удосконалювати інноваційно-технологічний розвиток, щуоб не втратити конкурентоспроможності та позицій на зовнішньому і внутрішньому ринку продовольства. Нововведення розширюють можливості сільськогосподарських товаровиробників, впливаючи на сочіально-економічний розвиток сільських територій. Тому є актуальним підвищення інтенсифікації сільськогосподарського виробництва на основі активного впровадження інновацій в аграрну сферу України. В даний час успішні фермери і влас- 
ники великих агрохолдингів почали всерйоз иікавитися сучасними технологіями обробки землі й тваринництва, а також високоефективною технікою. Вони готові суттєво інвестувати в свої землі- $і$ їхні інтереси знаходять підтримку у вітчизняних та іноземних партнерів. Об'єднання територіальних громадах (ОТГ) орієнтується на необхідність урахування $i$ законодавчого закріплення механізмів захисту інтересів периферійних сільських громад, підтримки кооперацї малих агровиробників, сприяння диверсифікації сільської економіки, шүо підвищить зайнятість та зменшить міграцію сільського населення. Це передбачає стимулювання підприємницької активності, диверсифікацію зайнятості сільського населення (зелений (сільський) туризм, промисли і ремесла, послуги), механізми впливу громадського самоуправління та регіонального саморегулювання на сочіально-економічні складові життедіяльності громад і територій.

Ключові слова: інновації, аграрний сектор АПК, диверсифікаџія, сільські території, територіальні громади.

Вступ

Сьогодні розвиток економіки визначається високою динамікою економіко-технологічних перетворень, що підсилюється конкуренцією в ряді галузей і призводить до змін потреб суспільства. Ці фактори виходять на перший план за рахунок стрімкого розвитку інформаційних технологій і глобалізації світової економіки, в таких умовах підприємствам аграрного сектору АПК необхідно постійно удосконалювати інноваційно-технологічний розвиток, щоб не втратити конкурентоспроможності та позицій на зовнішньому і внутрішньому ринку продовольства. Нововведення розширюють можливості сільськогосподарських товаровиробників, впливаючи на соціальноекономічний розвиток сільських територій. Тому є актуальним підвищення інтенсифікації сільськогосподарського виробництва на основі активного впровадження інновацій в аграрну сферу України.

Теоретичні і практичні аспекти інноваційної діяльності та розвитку сільських територій у своїх публікаціях розглядали науковці: Абрамов Л.К., Азарова Т.В., Борблік К.Е., Бородіна О.М., Важинський Ф.А., Залізко В.Д., Карпенко О.М., Колодязна І.В., Павлов O.I., Прокопа I.B., Томашук I.B., Шубравська О.В. та ін.

Метою статті є дослідити особливості впливу інвестиційно-інноваційної діяльності в аграрній сфері АПК на регулювання розвитку сільських територій.

\section{Матеріал і методи досліджень}

В процесі дослідження застосовувалися наукові праці учених $з$ проблем теорії та практики формування стратегічних напрямів інноваційного та сільського розвитку, загальнонаукові, аналітичні методи, Інтернет-ресурси.

\section{Результати та їх обговорення}

Сільські території відіграють важливу роль при формуванні іміджу держави на світовій арені, оскільки саме сільські території забезпечують продовольчу безпеку країни, яка $\epsilon$ частиною національної безпеки. Україна є державою, що володіє значними ресурсами для виробництва аграрної продукції, значну частину яких, безсумнівно, можна віднести до розміщення на сільських територіях. У цих умовах особливого значення набувають чинники підвищення конкурентоспроможності країн на світовому ринку. Головним із них $€$ інноваційна активність підприємств. В роботі (Kolodiazhna \& Borblik, 2017) зазначено, що в сучас- них умовах основним джерелом фінансування інноваційної діяльності вітчизняних підприємств виступають переважно власні фінансові джерела. За даними держкомстату (Zdiisnennia naukovykh doslidzhen i rozrobok u 2017 rotsi). У 2017 р. частка виконавців НДР (дослідників, техніків і допоміжного персоналу) у загальній кількості зайнятого населення становила $0,58 \%$, у тому числі дослідників - 0,37\%. За даними Свростату, у 2015 р. найвищою ця частка була у Фінляндії (3,21\% і 2,35\%), Австрії (3,10\% і 1,92\%) та Швеції (2,97\% і 2,33\%); найнижчою - в Румунії $(0,53 \%$ і $0,33 \%)$, Кіпрі $(0,83 \%$ і 0,61\%), Польщі (1,0\% і $0,75 \%)$ та Болгарії (1,0\% і 0,65\%).

Сучасний етап економічного розвитку країни характеризується високою залежністю від масштабів наукових досліджень і розробок, швидкості та ефективності впровадження нових видів виробів і технологій. Це $\epsilon$ актуальним тому, що основний ресурс аграрного виробництва - унікальний грунт чорнозем невибагливий в обробленні і відрізняється незвичайною родючістю. Чорноземи України становлять десяту частину в світі таких грунтів, а загальна площа наших полів така ж, як територія Великобританії. Не може не турбувати те, що кількість організацій Академії аграрних наук України, які здійснювали наукові дослідження i розробки, зменшилось із 119 у 2010 році до 86 у 2017 році, що становить 26,7\%. Хоча багаті грунти зумовили явний пріоритет рослинної сільгосппродукції над тим, що може дати тваринництво: ми постачаємо весь світ соняшниковою олією, але свинину змушені закуповувати за кордоном, все ж актуальним на сьогодні питанням є збільшення частки державної участі у фінансуванні інноваційної діяльності підприємств України.

\section{Таблиця 1}

Організації Національних академій наук України, які здійснювали наукові дослідження i розробки (Naukova ta innovatsiina diialnist Ukrainy) (од)

\begin{tabular}{lllll}
\hline & 2010 & 2015 & 2016 & 2017 \\
\hline Усього по Національних & & & & \\
академіях & 385 & 323 & 322 & 321 \\
Академія наук & 206 & 183 & 181 & 180 \\
Академія аграрних наук & 119 & 85 & 86 & 86 \\
Академія медичних наук & 37 & 34 & 35 & 35 \\
Академія мистецтв & - & 2 & 2 & 2 \\
Академія педагогічних наук & 17 & 13 & 12 & 12 \\
Академія правових наук & 6 & 6 & 6 & 6 \\
\hline
\end{tabular}

Для вдосконалення стимулювання інноваційної діяльності в Україні потрібен новий комплексний механізм стимулювання всього інноваційного процесу - 
від фундаментальних досліджень до впровадження розробок у виробництво. Створення такого механізму $\epsilon$ доцільним не тільки на державному, а й на регіональному рівні.

Для сучасної аграрної науки в Україні характерні декілька основних рис. По-перше, ії основні осередки зосереджені у закладах Національної академії аграрних наук України та у провідних аграрних вищих навчальних закладах. По-друге, організаційні засади аграрної науки, перелік наукових установ принципово не змінювались упродовж усього періоду незалежності. По-третє, в Україні зберігалася суттєва експериментальна база (земельні площі для експериментального землеробства тощо) для сільськогосподарських досліджень. По-четверте, частка сільськогосподарських наукових досліджень становить приблизно 15\% від усіх науково-дослідних робіт, які проводяться у країні: це є свідченням того, що загалом потенціал аграрної науки збережено. Напрямами подальшого розвитку аграрної науки мають стати: підвищення врожайності основних сільськогосподарських культур; розробка ефективних технологій енергозбереження; розробка заходів із захисту земельного фонду від ерозії та забруднення.

Класифікація сільських територій районного рівня (Borodina \& Prokop, 2010) свідчить, що майже їх третина характеризується складною ситуацією у демографічно-поселенський сфері й низьким рівнем доступності до базових життєвих умов і споживчих послуг.

Україна нарощує свій аграрний потенціал і сьогодні своєю сільгосппродукцією годує 174 країни. Поки, скажімо прямо, врожайність з одного гектара землі у нас поступається такою, наприклад, в Новій Зеландії або Швейцарії - незважаючи на те, що в цих країнах немає чорнозему. Причини цього прозорі: перш за все справа в нерозвинених технологіях вирощування земель, в неефективній, морально і фізично застарілій механізації. I тим не менше: уже зараз Україна - світовий лідер з виробництва та експорту соняшнику та продуктів його переробки. Наші щедрі землі дають всій планеті 11,2 млн тонн зерна соняшнику - кожне третє насіннячко в світі виросло в Україні. Закономірно перше місце у нас і з експорту соняшникової олії - 3,3 млн тонн на рік. У надходженнях валюти це дає країні більше, ніж експорт ІT-послуг і транзит газу (Innovatsii dlia APK).

Однак варто відзначити, що переважання традиційних моделей управління $є$ причиною неефективності частини агроформувань аграрного сектору АПК. Так, за даними статистики, кількість збиткових від загального числа рівень рентабельності продукції сільського господарства в сільськогосподарських підприємствах виробництво м'яса великої рогатої худоби у 2017 році склало 3,4\%, м'яса свинини 3,5\%, м'яса птиці - 7\%. У фермерських господарствах виробництво м'яса великої рогатої худоби та свинини є збитковим (відповідно $(-2,1$ та $-6,7 \%)$, а м'яса птиці становить лише 3,5\%. Лише високорентабельними є зернові та зернобобові - 25\%, соняшник 41,3\% (Silske hospodarstvo Ukrainy za 2017, 2018).
В даний час успішні фермери і власники великих агрохолдингів почали всерйоз цікавитися сучасними технологіями обробки землі і тваринництва, а також високоефективною технікою. Вони готові суттєво інвестувати в свої землі - i їх інтереси знаходять підтримку у вітчизняних та іноземних партнерів. Україна гордо влаштувалася на подіумах і за іншими аграрними напрямками: у нас друге місце $з$ експорту зернових і горіхів, третє - 3 виробництва та експорту ячменю та ріпаку. Остання культура, до речі, 3 кожним роком набирає популярності - адже ріпакову олію використовують для виготовлення біопалива. На жаль, наша країна все ще лише поставляє європейцям сировинний продукт - насіння ріпаку, навіть не переробляючи його в олію. Та й з експорту борошна ми лише сьомі в світі, але є можливості зростання.

За даними Інституту економіки та прогнозування НАНУ, чисельність найманих працівників у сільському господарстві зменшилася із 2 млн 753 тисяч осіб у 2000-му році до 687 тисяч у 2015 році. Ще 2,2 мільйона осіб зайняті в так званих особистих селянських господарствах, які не зареєстровані як суб'єкти підприємництва, через що вони практично перебувають поза полем трудового законодавства і соціального захисту населення. Технологічний рівень таких господарств надзвичайно примітивний - сапа, лопата, коса, зрідка мотоблок. Продукція, що виробляється тут, не вписується в жодні стандарти, особливо це стосується молока і м'яса. Ї̈і асортимент обмежений десятком найменувань - картопля, молоко, м'ясо, фрукти, кілька видів овочів та ягід. Зокрема, виробляючи понад 90\% всіх обсягів картоплі та 70\% овочів, ОСГ не можуть реалізувати чи спожити $30-40 \%$ iз них. Тим часом, інституції, які мали б допомогти селянам адаптуватися до умов аграрного ринку та знайти на ньому своє місце, досі не розвинені. Йдеться передусім про дорадництво та обслуговуючу кооперацію (Karpenko, 2017).

Одним з найважливіших завдань політики держави на сучасному етапі $є$ поліпшення стану сільської економіки і підвищення рівня життя населення на селі. Отже, деградація сільських територій триватиме й далі. Із 2,5 млн українських мігрантів, які виїхали за кордон протягом 2014-2016 років, жителі сільської місцевості становлять 40\%. Загалом протягом останніх 25 років сільська місцевість втратила 3,5 мільйона осіб, з карти України за цей період стерто понад 600 сіл, 369 знелюднені, але ще не зняті з обліку, 25\% населених пунктів втратили здатність народжувати дітей, показник народжуваності у селах утричі менший, ніж загальнодержавний (Karpenko, 2017). Тому справедливо в роботі (Vazhynskyi \& Haleliuk, 2013) що людський потенціал $є$ основним стратегічним ресурсом і головним чинником економічного зростання, який фактично формує соціальні умови реалізації економічних інтересів регіону, а ключовою характеристикою цих умов $є$ рівень життя його населення. Пріорітетність їі обумовлена високою значущістю для країни таких найважливіших аспектів, як підвищення ефективності сільськогосподарської діяльності та забезпечення продовольчої безпеки, збереження наявного земельного, інфраструктурного, ет- 
нодемографічного і людського потенціалу, відтворення природних ресурсів природного навколишнього середовища, що позитивно вплине на розвиток сільських територій. Цього можна досягнути в рамках новостворених територіальних громад, які повинні всебічно вирішувати ці проблеми.

В Україні вирощують понад 70\% видів сільськогосподарської продукції, якою торгують на світових біржах, при цьому тільки 1/10 частина агрокомпаній почала впроваджувати інновації в своїй роботі. Такі передумови роблять нашу країну відмінним майданчиком для розробки і впровадження інноваційних рішень. За останні 5 років інвестиції в AgTechстартапи у світі збільшилися в три рази, а в 2017 році збільшилися до $\$ 10$ млрд в рік. Таким чином - розвиток нових аграрних стартапів $є$ відповідю на зростаня населення Землі, загрозу дефіциту ресурсів та кліматичні зміни.

“Зробити це швидко, ефективно і з найменшими витратами можна, якщо компанія орієнтована на застосування готових перевірених рішень (це підходить так званим late adopters). Інший шлях - інвестування в стартапи або в розробку інновацій всередині компаніï, - каже Криволап.

Нагадаємо, в Україні близько 65\% усієї вирощеної продукції, зокрема, плодоовочевої, не доходить до споживача через погані технології зберігання (Innovatsii v APK).

Тому в роботі (Pavlov, 2013) автор відзначає, що на регіональному рівні сільських територій більшість 3 цих соціально- просторових утворень $\epsilon$ “відцентровими”, оскільки вони не перебувають в зоні впливу великих міст, а руральна складова середньостатистичного регіону представлена 19 районами й 1138 селами. Адміністративними центрами районів є переважно малі міста та селища, значна частина яких руралізувалися й не здатні виконувати функції опорних центрів розселення та обслуговування.

Одним із найбільш успішних прикладів ефективного функціонування інституційно-правового механізму інноваційного розвитку сільських територій може слугувати досвід країн-членів ЄС. Так, починаючи 3 Маастрихського меморандуму (1993 р.) ЄС розробив основи інноваційної політики з використанням системного підходу, при якому інновації осмислюються не як лінійний і односпрямований потік знань від стадії наукових досліджень до практики, а як вельми розсіяний процес навчання, що відбувається в складних i гібридних реляційних мережах. Відповідно, СС активно сприяє розвитку державно-приватних (досліджень) партнерств, транснаціональних мереж, інноваційно-орієнтованої політики закупівель та інноваційних інкубаторів. Для забезпечення сталого розвитку сільських територій слід вирішити наступні завдання: європейські концепції розвитку сільських територій, законодавчо закріпити в Україні як базу щодо підтримки розвитку сільських територій. Новостворені територіальні громади повинні розробляти механізми фінансування програм розвитку сільських територій. Ці механізми базуватимуться на вивченні законодавчих актів Європейського союзу. Управління розвит- ком сільських територій в СС здійснюється відповідно до територіальним підходом.

У країнах СС ідея модернізації та інноваційного розвитку сільських територій останніми роками активно впроваджується в життя. У Стратегії розвитку Європи до 2020 року наголошується на важливості досліджень та інновацій як ключових елементів у підготовці Європейського Союзу до майбутніх викликів. Орієнтирами - Спільної аграрної політики -до 2020 року також $є$ незамінність інновацій у підготовці європейського сільського господарства до майбутнього. В рамках бюджету Свропи до 2020 року передбачається виділення 4,5 млрд євро на дослідження та інновації в царині продовольчої безпеки, біоекономіки та сталого розвитку сільського господарства (Communication from the commission to the European Parliament). Отже, розвиток сільських територій стає одним 3 генеральних напрямків в єдиній аграрній політиці ЄС і програми розвитку сільських територій засновані на пріоритетах, встановлених регламентом ЄC, а фінансування здійснюється 3 Європейського сільськогосподарського фонду розвитку сільських територій (EAFRD) 3 обов'язковим фінансуванням 3 національних або регіональних бюджетів. Основні положення і рекомендації можуть використовуватися органами влади для формування ефективної системи сталого розвитку сільських територій. європейська модель розвитку сільських територій носить комплексний характер, а сільська територія розглядається як єдиний соціально-економічний і природний комплекс і відповідно заходи з розвитку сільських територій мають широкий спектр напрямків від збереження i зміцнення екосистеми сільського та лісового господарства до створення робочих місць на селі. Визначення сільського способу життя як нижчого за своїм рівнем та якістю, ніж міський, вказує на ієрархію відносин між містом як центром та селами як периферією.

Автором в роботі (Zalizko, 2014) зазначається, що 3 узагальнення наукових підходів до визначення інноваційного розвитку економіки сільських територій випливає, що знання, інформація та комп'ютеризація мають стати основою нового типу розвитку економіки. Проект СС “Підтримка впровадження сільськогосподарської та продовольчої політики” (Proekt YeS) передбачає вирішення питань у таких напрямках:земельна реформа, дерегуляція, безпека харчових продуктів,фітосанітарія та ветеринарія,державна підтримка і доступ до фінансування, дослідження й освіта, інфраструктура та розвиток сільських громад.

Варто зазначити (Tomashuk, 2017), що необхідною умовою розвитку сільських територій є вибір оптимальної структури ресурсного забезпечення для ефективної роботи в умовах динамічних змін, що відбуваються у зовнішньому середовищі. Інновації в системі місцевого самоврядування України можна розглядати також і як інструментарій розвитку територіальних громад. Однією $з$ найважливіших завдань політики держави на сучасному етапі $є$ вирішення проблеми поліпшення стану сільської економіки і підвищення рівня життя населення на селі. Пріоритетність їі обумовлена високою значущістю для країни таких най- 
важливіших аспектів, як підвищення ефективності сільськогосподарської діяльності та забезпечення продовольчої безпеки, збереження наявного земельного, інфраструктурного, етнодемографічного і людського потенціалу, відтворення природних ресурсів природного навколишнього середовища. Багато в чому вирішення зазначених завдань залежить від рівня розвитку сільських територій, ефективність функціонування яких в умовах підвищених зовнішньоекономічних і політичних ризиків вимагає розробки науково обгрунтованих теоретичних і методологічних положень щодо стратегій з використанням формалізованих інструментів виявлення закономірностей i прогнозування їх тенденцій в регіонах, що дозволяють враховувати сформовані соціо-екологоекономічні умови і наявні ресурси, що сприяють росту ефективності господарюючих суб'єктів сільської економіки, добробуту і якості життя населення.

Варто зазначити, що уряд узгодив проект "Про схвалення Концепції розвитку сільських територій до 2025 року", метою якої є створення умов для комплексного розвитку багатофункціонального сільського господарства і села в інтересах суспільства. Ця Концепція передбачає стимулювання підприємницької активності, диверсифікацію зайнятості сільського населення (зелений (сільський) туризм, промисли і ремесла, послуги), механізми впливу громадського самоуправління та регіонального саморегулювання на соціально-економічні складові життєдіяльності громад і територій. Реалізовувати концепцію Міністерство аграрної політики та продовольства України пропонує за такими напрямами:

- підвищення рівня якості життя сільського населення;

- охорона та збереження природних ресурсів у сільській місцевості;

- розвиток економіки села;

- удосконалення системи управління сільськими територіями;

- освіта й інформаційно-консультаційне забезпечення.

В основу успішної аграрної політики зарубіжних країн покладено принцип взаємопов'язаності аграрного і сільського розвитку. В Україні ж сільське господарство і село розвиваються за протилежними траєкторіями, що зумовлено головним чином економічним і політичним домінуванням інтересів корпоративного сектора аграрного виробництва та ігноруванням необхідності повноцінного продукування ним таких суспільних благ, як екологічна безпека та якість життя. Орієнтація на зближення аграрного і сільського розвитку в Україні диктує необхідність вдосконалення механізмів регулювання агропродовольчого комплексу з метою забезпечення розв'язання таких завдань: спонукання суб'єктів господарювання до ощадливого використання природних, соціальних, інфраструктурних ресурсів сільської місцевості, спрямування економічних результатів їх діяльності на забезпечення розширеного відтворення цих ресурсів; подолання деформацій в організаційній структурі сільського господарства; стимулювання диверсифікації діяльності суб'єктів господарювання та сільського населення; забезпечення реалізації інтересів жителів усіх видів сільських поселень (особливо віддалених, малих, гірських тощо), пов'язаних $з$ їх економічною діяльністю та доступом до суспільних благ і послуг у процесі реформування місцевого самоврядування, галузей соціальної сфери, а також модернізації розвитку інфраструктури.

Варто погодитися $з$ тим, що громада “як досить складне соціальне утворення, що має різноманітні зв'язки, стосунки, взаємодії, постійно зазнає змін” (Abramov \& Azarova, 2012). Розробка стратегіï і програм формування умов сталого розвитку сільських територій здійснюється на основі стратегічного планування як інструменту прийняття ефективних управлінських рішень в умовах мінливості та невизначеності зовнішнього середовища. В зв'язку з цим виявлення пріоритетних напрямків політики розвитку сільських територій на федеральному і регіональному рівнях, формування багаторівневої і міжвідомчої системи управління і фінансування розвитку села, своєчасне прийняття ефективних рішень, що дозволяють конструктивно використовувати наявні трудові, матеріальні і природні ресурси, стають найважливішими факторами сталого розвитку регіонів.

Для реалізації цього напряму сільського розвитку потрібно передусім активізувати консультаційну й навчальну роботу, а також сприяти доступу сільських жителів до мікрокредитування як інструменту покращення їхніх побутових умов і підвищення готовності надавати послуги сільської гостинності. Великий потенціал сільських територій закладено в можливостях розвитку диверсифікованої аграрної діяльності найменших господарств - ОСГ, у яких у середньому зайнято 45\% сільського населення працездатного віку. До 2020 р. це може забезпечити майже 2\% середньорічного приросту ВДВ у сільському господарстві за песимістичного сценарію, 4\% - за базового сценарію й $6 \%$ - за оптимістичного. Зазвичай села 3 високою часткою нереалізованого потенціалу ОСГ розташовані досить далеко від ринків збуту й мають ускладнений під’ізд (майже 85\% від їх кількості), що може бути компенсовано покращенням умов зберігання виробленої продукції, а малі масштаби виробництва консолідацією зусиль для формування більших партій агропродукції. Це можна вирішити за допомогою кооперації та створення різного роду груп найменших агровиробників. Так, наприклад, в Угорщині підтримка кооперації малих агровиробників посприяла диверсифікації сільської економіки: домінуючими напрямами неаграрної діяльності в них стали переробка фруктів і овочів, молочної продукції, а також виробництво вина. Крім того, за роки членства в СС (iз 2005 до 2013 р.) істотно збільшилася кількість господарств, що виробляють корми (втричі) й інші харчові продукти (удвічі).

Руралізація місцевого самоврядування як посилення селоцентризму в об'єднаних територіальних громадах (ОТГ) орієнтується на необхідність урахування і законодавчого закріплення механізмів захисту інтересів периферійних сільських громад у рамках масштабних міських, селищних і сільських ОТГ. При реформуванні превалює підхід інтегруючої ролі міст $\mathrm{i}$ 
селищ як точок зростання, а вже позитивні процеси їх розвитку мають бути поширені на сільську місцевість. Руралізація на практиці означає забезпечення децентралізації влади, ресурсів і послуг на рівні новосформованих об'єднаних громад.

Одним з пріоритетних напрямків розвитку сільських територій є збереження природних умов природного довкілля. Як зазначалося в роботі, в регіоні міністерством природних ресурсів і охорони навколишнього середовища реалізується державна програма “Охорона навколишнього середовища”, але при цьому заходи проводяться осібно, відомство ніяк не взаємодіє 3 іншими міністерствами, що істотно знижує спектр завдань, що можливо вирішувати в даній сфеpi.

Тому держава має виділити в рамках своєї програми розвитку сільських територій окрему підпрограму, основними завданнями реалізації якої $\epsilon$ : підтримка юридичних осіб, що реалізують інноваційні проекти 3 модернізації та створенню нових виробництв в сільській місцевості; надання субсидій на відшкодування витрат при впровадженні інноваційних технологій, спрямованих на екологізацію агропромислового виробництва в рамках сільських територій; надання податкових пільг підприємцям за створення додаткових робочих місць і залучення в економічну діяльність сільських мешканців; підвищення доступності інформаційних ресурсів в електронному вигляді, зокрема для надання послуг для населення в сільській місцевості. Іншим важливим напрямком $є$ розвиток ринку праці в сільській місцевості, як основні актуальні завдання тут можна відзначити: розробку заходів щодо працевлаштування громадян в сільській місцевості, організацію ярмарків вакансій і навчальних робочих місць; сприяння самозайнятості, організацію стажувань, практик для випускників в передових організаціях сільської економіки; забезпечення об'єктивної оцінки та реалізацію заходів, спрямованих на поліпшення умов праці та зменшення міграції сільського населення.

\section{Висновки}

В даний час успішні фермери і власники великих агрохолдингів почали всерйоз цікавитися сучасними технологіями обробки землі і тваринництва, а також високоефективною технікою. Вони готові суттєво інвестувати в свої землі - і їхні інтереси знаходять підтримку у вітчизняних та іноземних партнерів. Об’єднання територіальних громадах (ОТГ) орієнтується на необхідність урахування і законодавчого закріплення механізмів захисту інтересів периферійних сільських громад, підтримку кооперації малих агровиробників, сприяння диверсифікації сільської економіки, що підвищить зайнятість та зменшить міграцію сільського населення. Сьогодні розвиток економіки визначається високою динамікою економіко-технологічних перетворень, що підсилюється конкуренцією в ряді галузей і призводить до змін потреб суспільства. Ці фактори виходять на перший план за рахунок стрімкого розвитку інформаційних технологій і глобалізації світової економіки, в таких умовах підприємствам аграрного сектору АПК необхідно постійно удосконалювати інноваційно-технологічний розвиток, щоб не втратити глобальної конкурентоспроможності і позицій на внутрішньому ринку продовольства. Нововведення розширюють можливості сільськогосподарських товаровиробників, при цьому позитивно впливаючи на соціально-економічний розвиток сільських територій. Тому є актуальним підвищення інтенсифікації сільськогосподарського виробництва на основі активного впровадження інновацій у аграрну сферу України, що передбачає стимулювання підприємницької активності, диверсифікацію зайнятості сільського населення (зелений (сільський) туризм, промисли і ремесла, послуги), механізми впливу громадського самоуправління та регіонального саморегулювання на соціально-економічні складові життєдіяльності громад і територій.

Перспективи подальших досліджень. Провести дослідження соціально-економічного розвитку сільських територій, який базується на основних індикаторах оцінки соціальної інфраструктури, що становлять елементи організаційно-економічного потенціалу. Це дозволить проводити моніторинг конкурентоспроможності сільських територій та прогнозування перспектив їх розвитку.

\section{References}

Abramov, L.K., \& Azarova, T.V. (2012). Tsentr mistsevoi aktyvnosti dlia rozvytku hromady. Kirovohrad: ISKM (in Ukrainian).

Borodina, O.M., \& Prokop, I.V. (2010). Teoriia, polityka ta praktyka silskoho rozvytku. K.: In-t ekonomiky ta prohnozuvannia NAN Ukrainy (in Ukrainian).

Communication from the commission to the European Parliament and the Council. Rezhym dostupu: http://ec.europa.eu.

Innovatsii dlia APK. Choho chekaty vid "Ahro-2018" (2018). Rezhym dostupu: http://www.dsnews.ua/ economics/innovatsii-dlya-apk-chego-zhdat-ot-agro2018--05062018095500.

Innovatsii v APK vprovadzhuie tilky desiata chastyna kompanii. Rezhym dostu-pu: http://agravery.com/uk/ posts/show/innovacii-v-apk-vprovadzue-tilki-desatacastina-kompanij (in Ukrainian).

Karpenko, O. (2017). YeS protiahom 2014-2020 rokiv vydilyt na silskyi rozvytok 95,6 mlrd yevro. A Ukraina? Rezhym dostupu: http://infoindustria.com.ua/yes-protyagom-2014-2020rokiv-vidilit-na-silskiy-rozvitok-95-6-mlrd-yevro-aukrayina (in Ukrainian).

Kolodiazhna, I.V., \& Borblik, K.E. (2017). Dzherela finansuvannia innovatsiinoi diialnosti pidpryiemstv Ukrainy. Mukachivskyi derzhavnyi universytet. Ekonomika i suspilstvo, 9, 448-453 (in Ukrainian).

Naukova ta innovatsiina diialnist Ukrainy. Derzhavna sluzhba statystyky Ukrainy. Rezhym dostupu: http://www.ukrstat.gov.ua.

Pavlov, O.I. (2013). Identyfikatsiia silskykh terytorii Ukrainy yak peryferiinykh: teoriia ta praktyka. Sotsialno-ekonomichni problemy suchasnoho periodu Ukrainy, 6(104), 20-27 (in Ukrainian). 
Proekt YeS "Pidtrymka vprovadzhennia silskohospodarskoi ta prodovolchoi polityky". Rezhym dostupu: https://www.facebook.com/safpiu (in Ukrainian).

Silske hospodarstvo Ukrainy za 2017 (2018). Derzhavna sluzhba statystyky Ukrainy. Kyiv (in Ukrainian).

Tomashuk, I.V. (2017). Analiz ta statystyka resursnoho potentsialu silskykh terytorii ahrarnoho sektoru Ukrainy. Prydniprovska derzhavna akademiia budivnytstva ta arkhitektury: Skhidna Yevropa: Ekonomika, biznes ta upravlinnia, 5(10), 142-148 (in Ukrainian).
Vazhynskyi, F.A., \& Haleliuk, M.M. (2013). Resursnyi potentsial silskykh terytorii. Naukovi zapysky Lvivskoho universytetu biznesu ta prava, 10, 284-287 (in Ukrainian).

Zalizko, V.D. (2014). Silski terytorii Ukrainy: stratehichni prioritety rozvytku v konteksti zmitsnennia ekonomichnoi bezpeky: monohrafiia. Natsionalnyi universytet DPS Ukrainy. Irpin:Vyd-vo: NUDPSU (in Ukrainian).

Zdiisnennia naukovykh doslidzhen i rozrobok u 2017 rotsi. Derzhavna sluzhba statystyky Ukrainy Rezhym dos-tupu: http://www.ukrstat.gov.ua (in Ukrainian). 